\title{
Addressing Disasters: A Novelty for Many Orthodox Clinical Practitioners and Researchers in Psychology*
}

\author{
Antony James William Taylor \\ Victoria University of Wellington, Wellington, New Zealand
}

\begin{abstract}
This paper pays tribute to the practitioners and scholars who have extended their fields of interest to include disasters, and it raises questions that arose from personal involvement in a few of such extraordinary events. It is written in the hope of encouraging more novitiates to broaden their perspective and respond to the academic and professional challenges that calamities provoke. The outcome should also do very much to demonstrate that psychology is both an academic and an applied discipline.
\end{abstract}

Keywords: definitions, classification, epistemological dissonance, macro-issues, micro-issues, standard and novel

\section{Introduction}

Disasters of one kind or another have occurred since the dawn of mankind. Historically, they were in the form of droughts, earthquakes, famines, fires, floods, hurricanes, land-slides, pestilence, plagues, storms, tsunamis, and volcanic eruptions. At the extreme, many brought massive loss of life, ruined seasonal crops, demolished communities, and sometimes destroyed whole civilizations.

Pre-scientific explanations for such calamities involved the assumption that members of suffering communities had offended their Gods through major sins of commission or omission. Recovery required the identification of key transgressions, the acceptance of blame, and the application of appropriate redemptive measures. The early Romans adopted the Greek Sibylline Books as a guide in such matters, and they appointed a small group of scholar/custodians to identify the remedies (Retrieved December 14, 2011, from http://en.wikipedia.org/wiki/ Sybilline_Books).

The emergence of natural science in the 18th century as a rational pursuit in the acquisition of knowledge, prompted a search for other types of explanation. The matter became more acute when the industrial revolution brought accidents of major proportions that fell outside the speculative metaphysical sphere ${ }^{1}$. It also required the catalogue of catastrophes to be broadened to include disasters in manufacturing plants and mining, from major transport accidents on land/sea/air and in outer space ${ }^{2}$, and from the use of nuclear weaponry that “progress” occasioned.

\footnotetext{
* Developed substantially from an invited contribution to a publication edited by George Doherty (2010), and presented to the 2012 joint annual conference of the New Zealand Psychological Society and the New Zealand College of Clinical Psychologists. Antony James William Taylor, Ph.D., emeritus professor, retired from Victoria University of Wellington.

${ }^{1}$ Yet today some individuals, groups, and communities still cling tenaciously to primitive explanatory beliefs, no matter how inadequate those explanations might be.

2 See Harrison, Taylor, and Wichman (2009) for an invited chapter on the effects of an asteroid or comet striking the earth. Also consider other kinds of potential hazard that might jeopardise the outcome of manned Moon/Mars flights (Retrieved July 1, 2010, from Astronaut Health Care System Review Committee, February-June, 2007).
} 
In 1947 the "cold war" between former allies USA and the Soviet Union led the Board of Directors of the Bulletin of the Atomic Scientists to dramatise the urgency of the day by invoking the notion of a "doomsday clock". They warned that the closer the hands were to midnight, the closer was the risk of a global disaster. Then, with the spectre of World War II atomic bomb devastation on Hiroshima and Nagasaki fresh in mind, the Board set the hands at seven minutes to midnight. Subsequently, the Board moved the hands 20 times to reflect changes in the prevailing tension between nations and the wider acquisition of weapons of mass destruction. It included threats of catastrophe from wars in space, and the prospect of a prolonged "nuclear winter" from accidents that might occur in the new generation of power stations. Currently, with the devastating effects of climate-change and conflicts in the Middle East coming into consideration, the hands stand at five minutes to midnight (Retrieved September 18, 2013, from http://en/wikipedia.org/wiki/ Doomsday_Clock - accessed) 3 .

Now, rather than detail any specific disaster, this paper offers a generic definition of disasters, and presents a unique model that integrates different kinds of them. Then it opens a few macro and micro-issues that arose serendipitously during the course of actual disaster work, and describes the tentative steps taken towards their resolution. As a result, it emphasises the place of psychology in social rather than either biological or experimental science, and shows the field to be challenging for academic and applied psychologists. Finally, it makes an appeal to psychologists to hearken to the tenets of a general systems theory that respects interdisciplinary endeavours (Miller, 1991), and reminds them not to ignore the residual resistance of researchers in their own disciplines to such a proposition ${ }^{4}$.

\section{Definition, and a Model to Integrate Disasters}

When the author entered the field in 1979, he searched for leads after promoting a study of body-handlers involved in the Mt. Erebus air-crash (Taylor \& Frazer, 1981). Numerous reports of different types of disaster were scattered in various publications, mostly in medicine and sociology. Practitioners and researchers had defined disasters by their cause, number of casualties, amount of damage, extensive area affected, financial cost, and difficulty in restoring the status quo (Taylor, 1980, ch.2). None had provided a helpful overview of all types of disaster for the neophyte. After several attempts to fill the gap, the author came to define disasters as catastrophic events that seriously disrupted the functioning of communities, created death and destruction, caused substantial harm to people, and made recovery difficult without extra help from outside agencies.

By way of a synthesis, the author prepared the first of what came to be a progressive series of models to encompass the variety of disasters (Taylor, 1987; 1990; 2007, the latest of which appears in Figure 1).

Thus a three-dimensional figure can be constructed to encapsulate the primary destructive forces, the major domains concerned, and the different phases of disasters.

Turning from the classification of disasters to their effects on individuals and their communities, the author preferred the word casualty to that of victim for those adversely affected, because it carried the

\footnotetext{
3 The editorial board of Disaster: Journal of Disaster Studies, Policy \& Management, 2006, 30, devoted the entire volume to forebodings about the effects of climate change. The issue was, and still is, very controversial, with both sides clouding the facts. As at January 25, 2010, the presentation of front-man Al Gore for one side could be seen at http://www.youtube.com/watch?v=Jxi-OlkmxZ4, and front-man John Coleman for the other at http://www.kusi.com/home/ 78477082.html?video $=$ pop\&t $=$ a.

${ }^{4}$ With acknowledgements to clinicians in the Australasian Society for Traumatic Stress Studies, and emergency personnel in the Australasian Critical Incident Stress Association for their pioneering work in linking professionals in the Southern hemisphere involved with disasters. Credit is also due to Douglas Paton of the University of Tasmania for underpinning such endeavors with the Australasian Journal of Disaster \& Trauma Studies, and John McClure of Victoria University of Wellington for leading research into decision-making to disaster-preparations (as cited in McClure, Willis, Johnston, \& Recker, 2011).
} 
implication of survival being a transitional rather than a terminal state. The word also avoided either transmitting or confirming the connotation of despair and helplessness to those who had suffered, and it reminded helpers to foster recovery by fostering the inner strength of those afflicted at the outset, instead of playing a more dominant role themselves.

\section{Figure 1 A Conceptual Model to Integrate Disaster Studies}

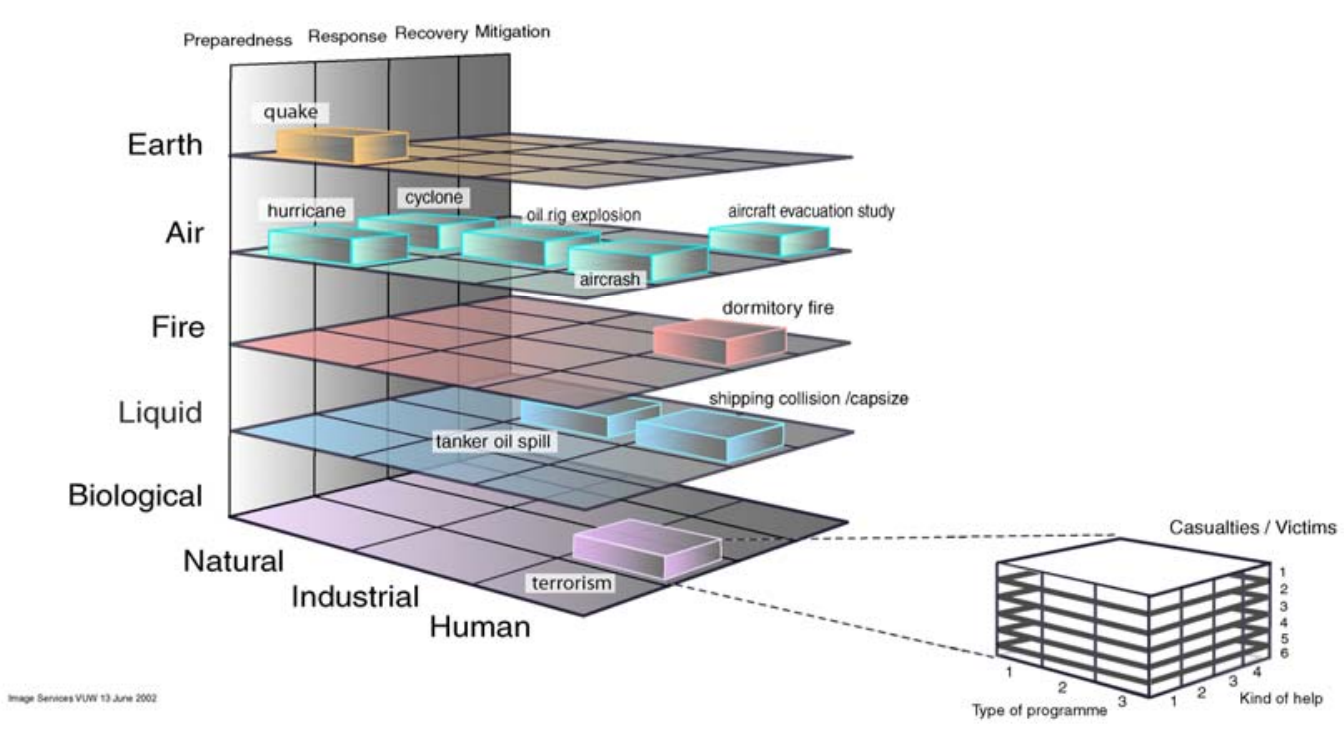

Figure 1. A conceptual model to integrate disaster studies.

With that proviso, an additional three-dimensional model was created to cover the somewhat different response from helpers that disparate groups of casualties might require to facilitate their personal recovery. Thus one dimension was designed to differentiate the major groups of casualties, a second to indicate the kind of intervention offered, and a third to cover the duration of such intervention (Table 1).

Table 1

The Somewhat Separate Categories of Disaster Casualties

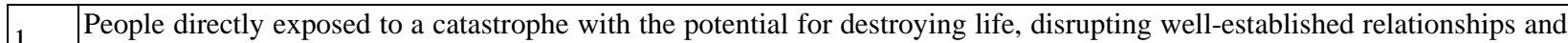
$1 \quad$ patterns of behavior.

$2 \quad$ Family and friends with close personal ties to the primary casualties, who themselves share severe grief reactions.

3 Organisational staff whose duties require them to report to respond to any major alert in the community and those who 3 assist with any subsequent rehabilitation and restoration work.

4 The concerned and caring members of communities beyond the impact area who often express their intentions with $4 \quad$ inappropriate goods and services.

5 Individuals and groups in proximity to disaster areas who lose their self-control and either share the suffering unduly or take advantage of the situation for personal benefit.

$6 \quad$ The miscellaneous group expressing anxiety who but for chance might have been primary victims, either refrained from sharing their premonitions, or actively induced people to enter situations in which they became primary victims.

The indefatigable sociologist Drabek (1986) took a different line. He synthesized the common features of nearly 1,000 reports of disasters, and found four relatively distinct sequential phases, each with two subsidiaries, and six somewhat distinct system levels. He named the phases "preparedness, response, recovery and mitigation”, and differentiated the system levels according to their focus on either individuals, groups, 
emergency organizations, entire communities, society at large, or the wider international scene. His resulting 8 $\times 6$ matrix provided a comprehensive overview of disasters in general, and led to specific disasters of immediate concern. More recently he clothed his skeletal theoretical structure with compelling vignettes of the actual suffering and recovery of many people from catastrophe (Drabek, 2010).

Archaeological journalist David Keys (1999) took yet another tack. Instead of attempting either to integrate disaster studies or to search for common factors running through them, he focused on the sequential effects of a single catastrophic event of mammoth proportions that occurred in AD 535 in South East Asia that had world-wide repercussions. Whether the particular disaster was caused by an asteroid collision with the earth, a falling comet, or a tremendous volcanic eruption is unknown. But there was compelling evidence of the event ejecting millions of tonnes of debris into the atmosphere that blotted out the sun for at least 18 months. The loss of light and warmth for so long a period destroyed all species of flora and fauna, and had far-reaching consequences for mankind.

Pulitzer Prize winning physiologist-cum-geographer Jared Diamond (1999; 2005) followed the same route to link several different kinds of disastrous consequences that affected the rise and fall of entire civilizations.

Social scientist Kai Erikson (1994) was more pragmatic and circumscribed than other researchers in his appraisal of disasters. As a consultant in a complex compensation case following a severe flooding, he identified a linkage between four different types of disaster that plaintiffs in the backwoods had suffered, i.e., a dam burst, the subsequent destruction of a community, the loss of livelihood, and the resulting economic dependency. The finding prompted him to draw attention to three significant matters. The first was the absence of a theoretical model with which to grasp the common factors suffered by individuals in different kinds of adversity. The second was to bring community and cultural dimensions of loss into consideration. The third was to appeal to researchers to develop methods to encourage victims to reveal the richness of their experience, instead of expecting them to respond to standard predetermined questionnaires that provided objectivity at the expense of validity. In doing so, he argued that, in the disaster field at least, natural scientists and technologists had social responsibilities to fulfill.

\section{Macro-issues in Disaster Research}

The neglect of social responsibility by scientists, natural as well as social, is still a vexed question. Consider: (1) the neglect of white-collar criminality until Sutherland (1949) opened the topic; (2) the more recent devotion to free-market economic policy with little regard to its destructive consequences (Taylor, 1991); (3) the urgent need to study factors behind the resurgence of international terrorism (Silke, 2003, pp. xv-xx1); and (4) the ready acceptance of "collateral damage" affecting unarmed civilians during warfare (Retrieved December 24, 2011, from http://en.wikipedia.org/wiki/Collateral_damage).

In the last two decades, the consequence of such a quatrain of avoidance has been severe. The misery from fraudulent schemes perpetrated by the scions of commerce still reverberate ${ }^{5}$, and the worship of "free-market" economic theory has enabled corporate conglomerates to place monetary values far above the livelihood of

\footnotetext{
${ }^{5}$ The flush of deregulation also led many financial companies to abandon prudence in their dealings, and to become the respondents in civil action, if not the accused in criminal proceedings. The measured appraisal of such "corporate malevolence", its causes and widespread effects, has yet to emerge. Consider the debacles of BCCI, Barings Bank, Andersons and Enron Energy, Xerox, Worldcom, Merril Lynch in the USA, insider trading at Lloyds of London, Elf Acquitane in France, LG Card in Korea, Akold in the Netherlands, Parmenter Corporation in Italy, Allied Irish Bank, Ariadne, Reid Murray and HIH Insurance in Australia and JBL, Equity Corporation and Ansett in New Zealand.
} 
individuals and the well-being of their local communities (Korten, 1996; Bakan, 2004) ${ }^{6}$. There lay the seeds of discontent. In dealing with them, authoritarian governments paid lip-service to human rights (Burns, 2006). Regrettably, since 1948 the lofty aims of United Nations to resolve conflict by peaceful means have yet to be realised.

In 1995, for the first time, the IFRC\&RCS (International Federation of Red Crescent and Red Cross Societies) expressed its concern about the "disaster inducement work of powerful self-promoting economic and political groups” (IFRC \& RCS, 1995, p. 52). Three years later it included specific areas of socio-economic dislocation in its map of relief operations (IFRC \& RCS, 1998, p. 188) ${ }^{7}$. The subsequent global extension of the "free market" led the World Commission on the Social Dimension of Globalization (2004, p. vii) to preface its report with a dire warning about the economic disparities that had worsened the lot of poorer nations, lest "the world we all share slide into further spirals of political turbulence, conflicts, and wars”. It went on to assert that:

The governance of globalization must be based on universally shared values and respect for human rights. Globalization has developed in an ethical vacuum, where market success and failure have tended to become the ultimate standard of behaviour, and where the attitude of "the winner takes all" weakens the fabric of communities and societies. (World Commission on the Social Dimension of Globalization, 2004, p. 7)

In making its stand, the World Commission presaged Wilkinson and Pickett's (2009) “disparity thesis" by a few years. In a detailed study, the latter argued that the greater the monetary gap between the relatively few in a country or a state holding the top $20 \%$ of gross national income and the larger number holding the bottom $20 \%$, the greater the adversity to be seen on a number of important social indicators. The subsequent series of economic crises has only accentuated the differential between groups.

\section{Terrorism}

In the last 15 years, terrorism, the third in the list of neglected disaster topics, became more prominent and complex a problem. Defined as the strategy adopted by a militant minority to achieve political ends by maximizing damage and disruption for the civilian population of a target country, it focused on nodal points such as communication centres, food and water supplies, power grids, and transport networks (Lacquer, 1987; Silke, 2003).

There again, not long after the terrorist attack of September 11, 2001, on the World Trade Center in New York (The 9/11 Commission Report, n.d.), President James D. Wolfenson of the World Bank, reiterated his concern that poverty and inequality were at the root of global ills that generated terrorism (Retrieved December 15, 2011, from http://www1.worldbank.org/finance/html/world_bank_and_aml-cft.html). Then in 2005, Secretary-General of the United Nations Kofi Annan appealed for member countries to adopt a common outlook of global citizenship with humanitarian as well as economic concerns (The Madrid Declaration, Retrieved December 19, 2011, from http://efus.eu/en/topics/risks-forms-of-crime/terrorism/ partners/183/).

\footnotetext{
${ }^{6}$ Aid worker Giles Bolton (2008) provided a gritty first-hand account of the futile attempts by leading international agencies to improve the living standards of many African nations. He traced the interventions from imperialist days to the present, arguing that the dysjunction between the assumptions and expectations of the donors and the recipients needs substantial change. He showed how the Western belief in the allocation of money to solve all basic problems, without first involving countries in assessing their basic needs and in developing administrative infrastructure and services to meet them, has been a constant recipe for disaster.

7 The latest report of Refugees International shows that in 2010 there were 43.7 million people displaced in the world, 15.4 million of whom were refugees seeking asylum (Retrieved December 15, 2011, from http://www.unhcr.org/4dfb65ef9.html). Although it did not specify the economic status of refugees, it would be foolish to think that without work, property and possessions, their level of subsistence was other than precarious.
} 
Soon afterwards, the United Nations General Assembly (2005) endorsed the theme of Madrid, and it urged adherents to redress their priorities to avoid further catastrophe. On August 10th of the same year, Paul Hunt, a human rights legal advisor to the United Nations (Retrieved from http://www.essex.ac.uk/human rights_centre/research/rth/docs/Paul_Hunt_profile.pdf), addressed the School of Government at Victoria University of Wellington NZ on the abuse of economic, social and cultural rights, and he put the matter among the most important and challenging issues of the day. The very next week, at a National Counter Terrorism Capability Seminar in the same setting, political analyst Kumar Ramakrishna (2005) of Nan Yang Technological University (Retrieved from http://www.rsis.edu.sg/about_rsis/staff_profiles/Kumar.html) in Singapore identified the three main roots of terrorism as a striving for political ascendancy, the elaboration of an ideology, and a pervasive discontent with the "status quo" reflecting social injustice.

Subsequent warnings and appeals to governments to address the causes of economic disparity were unheeded. A monetary "melt-down" ensued that has still to be addressed and rectified. Despite their fiercely-held credo of economic independence, major American and British banks were among the first to appeal for a bale-out from their governments (Bollard \& Guitanos, 2010) ${ }^{8}$. In turn, under the guise of short-term expediency, governments imposed measures that produced severe effects on the most vulnerable of their citizens ${ }^{9}$. Moreover, they left the unpalatable prospect of communities having to accept the recurrent cycle of bank failures in bad times without recompense when times are good.

Sadly, such calamities rarely feature in the proceedings of any social science discipline. At least in 2012, the ESA (European Sociological Association) Research Network 8 DCSCRN ("Disaster, Conflict and Social Crisis Research Network”) did put the social impacts of the debt crisis in the Eurozone (Portugal, Italy, Greece, and Spain) on its interim conference - the effect of which remains to be seen.

\section{Warfare}

In recent years, the tally of countries involved either internally in civil wars or externally against other nations is extensive (Retrieved December 19, 2011, from http://en.wickipedia.org/windex. php? title=Modern_ warfare\&oldid=465813145). In many countries, the "military-industrial complex" commands a substantial chunk of the budget that might otherwise be spent on improving the health, education, social justice, and welfare of a community. The total cost of belligerence in human and monetary terms beggars description, but they it has yet to yet to be regarded as tantamount to disastrous.

At least, on November 26, 2011, the International Federation of Red Cross and Red Crescent Societies adopted a groundbreaking resolution affirming that the use of nuclear weapons would be incompatible with the rules of international humanitarian law. It appealed to all member countries to prohibit the use of nuclear weapons, and to engage in public education and dialogue on the crucial matter (Retrieved January 3, 2012, from https://sites.google.com/site/abolitionupdates/december-2011/successful-abolition-2000-annual- generalmeeting).

The argument in this paper is not that disaster researchers should necessarily be active personally in

\footnotetext{
${ }^{8}$ Having said that, it should be pointed out that on the investment front, Harry S. Dent (2009) was supremely confident that a careful observance alone of the long-term cyclical fluctuations in stocks, real estate and commodities, would reveal the route for economic recovery.

9 The protest began separately in America, Britain, Greece, Italy, and Spain in 2009/2010, and soon spread to other countries locked into the web of economic failure. The protesters sought solutions other than those provided by bankers and economists who wielded power over them.
} 
examining all of such macro-issues, but that they should not ignore them as they pursue micro-issues with which they are more familiar in their own academic disciplines.

\section{Micro-issues in Disaster Research}

Micro issues can be either standard or novel. Standard issues are those than should be covered during basic academic and professional training courses and subsequent post-graduate updating. Novel issues are those that come to attention unexpectedly during the conduct of research and require tentative answers at the time, but detailed consideration later.

\section{Standard Micro-issues}

Standard micro-issues concern the ethics, epistemology, methodology, methods, reliability and validity of scales for different target populations, and the problems expected to arise in disaster research. They also include an appraisal of previous endeavours others might have used to solve similar problems ${ }^{10}$. Practicalities begin by gaining permission to enter restricted areas, with the assurance of logistic support and security without adding unduly to the burden of authorities on the ground. Thereafter clinicians and researchers themselves are responsible for creating and maintaining routines and procedures to prevent compassion fatigue as they fulfill their professional functions (Figley, 1994).

Thanks to Human Rights legislation, clinicians and researchers are obliged to gain ethical approval or risk prosecution before launching their projects. Fortunately, Ronald Francis (1999) provided a helpful guide for psychologists who in their pursuit of "scientism" neglected the study of philosophy that once spawned their subject. Alas all too soon forgotten have been:

(1) the so-called medical "experiments" in Nazi concentration camps in occupied Europe (Russell, 1955) and Unit 731 in Manchuria (Williams \& Wallace, 1989);

(2) the conduct of CIA sponsored sensory deprivation studies at McGill University and elsewhere in the 1960s (Victorian, 1996);

(3) the professional codes that once gave priority to the welfare of narrowly-focused experimenters over the concerns of their subjects (Pappworth, 1967).

A somewhat related concern is the appropriate epistemological balance that clinicians and researchers strike between objectivity and subjectivity in the conduct of their practice and research. Invariably one extreme leads to dogmatic determinism, and the other to intellectual nonsense of the kind that physicist Alan Sokal's (1996) fabricated and the editors of the well-meaning post-modernist journal "Social Text" took on trust and published $^{11}$.

The exposé illustrates the long-standing tension between psychologists who seek recognition as pure scientists and those who are intent on applying their skills in the service of mankind. US Navy Commander Newell H. Berry presented a forthright paper on the topic to the 1968 London Conference of the British

\footnotetext{
10 Tribute must be paid to social scientists Paul Carney, Anne M. Dietrich, Denruth Lougeay, Hope Morrow, and Bruce Young for providing up-to-date Websites of research publications over the last three decades, and to the interdisciplinary disaster mental health professionals for offering collegiate support at critical times (Retrieved from Disaster_Mental_Health_Professionals @ yahoogroups.com).

11 The sociologist editors of the Journal, David Bloor, Barry Barnes, and Bruno Latour, had advocated the use of novelty to break the fetters of experimental method that were inappropriate for their discipline. To their embarrassment, the physicist Alan Sokal presented a paper that parodied their intentions. Fanellii (2009) pointed to flaws of character of which scientists have to beware in themselves and the experimenters in whom they trust.
} 
Psychological Society. He was critical of the relevance, methodology, outcome, and utility of a sample of some 4,000 research reports that his government had sponsored from psychologists. More recently, Kerry Chamberlain (2009) addressed gatherings of the British and the New Zealand Psychological Societies on the same issue. Evidently the production of satisfactory research had hardly improved over the previous 40 years ${ }^{12}$. Then in 2010, the Townsend/Walker team at UK Nottingham University focused on 708 studies of interventions connected with serious behavioural and clinical issues presented by young offenders. They found only 10 in which the methodology conformed to acceptable criteria ${ }^{13}$.

However, more recently the 2nd International Conference on Cognitive and Behavioural psychology promised a dramatic broadening of the discipline's conventional epistemological focus. Its promotional material declared that:

Going beyond the study of the human mind, academics and professionals working in the field of psychology now play a pivotal role in promoting the development as well as recovery of mental health on a global scale... Psychology professionals now more than ever are being called upon to respond to the needs of society and individuals experiencing crisis in different forms such as war, famine, economic turmoil, crime, murder, abuse, loneliness, and despair. (Email of March 21, 2012)

May the broadening of the theoretical and epistemological model take a firm hold against the institutional imperatives that have dominated many psychologists thus far.

\section{Novel Micro-issues}

Like the fabled Princes of Serendip, researchers and clinicians have to be ready to seek answers to new questions that emerge from empirical work. Fresh tracks will take them into uncharted experiential and intellectual territory where they are likely to encounter the unexpected. For example, in places such as Polynesia, western-trained researchers must be prepared to present their credentials publically as human beings, rather than to shelter behind a formal list of academic qualifications and professional expertise. At the outset, local communities want to know their marital and family connections, their personal beliefs and values, previous experience and present motives, before giving their full cooperation.

For the author, the catalogue of such matters that emerged from such disaster research to require attention included:

(1) familiarity with the major cultural framework of a target population;

(2) the inadequacy of mortuary facilities and services and the perceptual defence spontaneously adopted by body recovery workers;

(3) recognising the metaphysical component of personality and of group membership, and accommodating it within an explanatory system to account for disasters;

(4) discovering the social structure of the target community;

(5) being alert for both familiar and unfamiliar sign and symptom-patterns;

(6) confirming the therapeutic value of group cohesion;

\footnotetext{
${ }^{12}$ As an occasional reviewer for international journals, the author has been saddened by the disparity between the outstanding ability of some researchers to process data and their judgment as to its relevance for solving the problem under investigation. Also, in some research sectors a free-for-all seems to occur after major disasters, when everyman and his dog get loose as experts.

13 The author is pleased to say that his $\mathrm{PhD}$ evaluation of the effects of group therapy with young female offenders experiencing mood and anxiety disorders and self harm, was ranked fourth out of the 10 studies that met the criteria for methodological acceptability.
} 
(7) considering the timing and efficacy of subsequent specific interventions;

(8) noting the power of the placebo effect in fostering self-help;

(9) realising the function of humour in helping individual and group recovery;

(10) finding the value of debriefing community members in situ rather than by recall later in a consulting room;

(11) having a positive role for the media in post-disaster management;

(12) collecting data for clinical and research purposes;

(13) sundry miscellaneous matters.

\section{Addressing Such Items Sequentially}

(1) To avoid being lost in a confusion of definitions, a culture can be defined as an integrated and enduring system of activities, attitudes, beliefs, customs, procedures, and relationships that differentiate people of one society from another. Parents and authority figures transmit it to their children by example and word of mouth. It is built over centuries, and remains largely unwritten except by anthropologists either seeking common elements or making unique features available for others. It sets the framework that allows professionals to practice safely when working either in their own culture with immigrants and refugees from elsewhere or abroad in foreign parts.

To its credit, the staff of NZ Foreign Affairs oriented disaster recovery staff to the different cultural scenes after a cyclone on Manihiki, a dormitory-fire in Tuvalu, and a hostage assignment in Fiji. Later in each place, the author was able to recruit local people for their expertise, for smoothing cultural access, acting as interpreters when necessary, and continuing liaison afterwards (because they would have to bear the continuing brunt of any recovery while the "clinical expert" returned home) ${ }^{14}$.

To give another example, after the 1979 Air New Zealand air crash in the Antarctic the mortuary staff in Auckland had to contend with the unexpected cultural obligation of Japanese relatives pressing the authorities to facilitate their travel to the frozen continent to pay their personal respects at the site of the tragedy. To a lesser extent, the relatives of other national/religious groups applied pressure for the authorities not to leave the bodies of their loved ones alone, but to conduct their operations without unnecessary delay and then to allow them to begin the cycle of their cultural obligations.

Just wise, patient, and sympathetic management on the part of the police prevented the outbreak of trouble, because logistically in neither case was it possible for the authorities to accede immediately to the demands of families. However, it would have helped had they known enough to have anticipated the family obligations, and had the mortuary been designed with room for the families and their clergy to begin to pay their respects to the deceased.

(2) As for the particular mortuary that was central for ascertaining the precise cause of death and the identification of victims after the Air New Zealand DC10 crash in Antarctica, even its basic facilities were found wanting. Although it was the only mortuary in a big city, a part of a medical school, and had been constructed only three years previously, it had not been designed for a large-scale emergency. It had insufficient freezing and cooling chambers, an awkward layout that made for difficulty in moving the bodies

\footnotetext{
${ }^{14}$ Visiting staff also have to be prepared to work through any residual resistance that different groups might carry towards each other as they undertake fresh disaster work, and be ready to tackle any resentment from "old hands" for having been selected to play a key role instead of them.
} 
through the facility, no lifting equipment, insufficient protective gear for the augmented mortuary staff to wear (Taylor, 1984).

Nearly 20 years later, the Occupation and Safety Division of the Department of Labour in New Zealand (Health \& Safety in New Zealand Mortuaries, 1998) found that only one of the 16 mortuaries in the country still had facilities and practices that were up to standard.

To its credit, the WHO (World Health Organization) (2004) emphasized the socio-cultural obligations of personnel handling human remains and set out the requirements for temporary field-mortuaries. But it left aside the perceptual defense that emergency personnel came to adopt when handling carnage, and the inadequacy of existing mortuary facilities in metropolitan areas that originally had aroused the author's interest (Taylor, 1984).

In a word, those engaged on handling human remains after a disaster achieved emotional distance by casting their work in terms with which they were familiar, i.e., like handling waxworks, broken dolls, frozen meat, or jigsaws. Their spontaneous strategy could be mentioned to advantage in the training of other emergency personnel (Doherty, 2007) ${ }^{15}$. Afterwards, like actors after every intense performance, they would need to "de-role" and return to function as normal human beings.

(3) Disasters challenge the "modus vivendi" of people and their communities. They shake reliance on the status quo, raise questions about the justification for the life-threatening events that have occurred, and promote a search for fundamental meaning that promises to give security in times of uncertainty. For many, the argument centers on metaphysical factors that involve the imposition of Divine punishment for the unspecified moral transgressions of whole communities. A few emergency workers after the air crash in the Antarctic, like most of the survivors of a cyclone in the South Pacific, were content to attribute the events to departures from righteousness on the part of the communities affected. They stopped short of reflecting on either their own anxiety over the denial of death (Becker, 1973) or even perhaps its antithesis, the desire to hasten their own death (Retrieved January 29, 2009, from http://www.religioustolerance .org/isl_jihad.htm; Ali, 2003).

On neither occasion did the author think it appropriate to question such beliefs at the time they were disclosed $^{16}$. Although the author did suggest to one person that victims of the air crash might have belonged to other faiths with different world-views, and to another, when pressed publicly in a situation in which the author was expected to reply, that more appropriate explanations for the recurrent annual cyclones of lesser magnitude might be found in climatology and oceanography rather than theology.

The author left aside for later consideration, the points that:

(1) The God of the New Testament would have offered acceptance and forgiveness rather than

\footnotetext{
${ }^{15}$ Subsequently, the strategy was applied: (1) in the training of occupational therapy teachers to alleviate their anxiety in working with human tissue in muscle prosecution classes (Hancock, Williams, \& Taylor, 1998); and (2) with medical students working on cadavers in their pathology classes (Hancock, Williams, Taylor, \& Dawson, 2004).

${ }^{16}$ The monotheistic explanation for disasters remained and still remains central to the existence of the Cook Islanders (South Pacific Bureau for Economic Co-operation, 1979), although traces of earlier polytheism are still there (Luomala, 1984). Yet paradoxically, official quarters had voiced concerns about global climatic warming and associated sea level changes (Brook, Basher, Bruce, Parsons, \& Sullivan, 1991, p. 2). The Islands government had also embarked on a five-year planning scheme, set priorities, and improved managerial infrastructures for coping with disasters (UNDRO, 1990). On this matter scientist have no cause to be smug, They might reflect on Sagan's (1997) thesis about the inevitable conflicts between irrationality and rationality that have arisen in the development of science. They might also take heart from Tenner's (1996) cautionary tale about the unintended consequences of so-called technological progress, and come to appreciate that the findings of science and technology, like those of scholarship, are not always beyond dispute!
} 
extermination for transgressions;

(2) The same God would not have punished the many for the behaviour of a few (more especially when a baby and devout clergy were among the victims);

(3) The acceptance of scientific explanations does not diminish the spiritual core of religious belief (Taylor, 1999) ${ }^{17}$.

Personally, as a Quaker and a clinical psychologist, the author was not, and is not, averse to the interplay of religion and therapy. The link affirms a belief that there is inner strength, that of God, in every person. The emphasis also happens to be consistent with both NZ Maoridom's emphasis on the mental/physical/social and spiritual components of existence (Durie, 1985), and with O’Donohue's (1989) appeal for clinical psychologists to add the metaphysical dimension to the commonly held scientist/practitioner model for the assessment of human behaviour.

The attribution is worthy of reappraisal because of the frequency with which casualties of disaster allude to religious beliefs to account for the trauma they experience. Not that religious adherence necessarily guarantees a conflict-free life-In fact, the evidence shows it to have fostered bigotry and fanaticism that at times created more terror than tolerance. But religion can provide a code for living that might comes to the fore to help individuals and communities recover from trauma (Miller, 1999).

The clergy opened the topic in the 1950s in the field that came to be known as pastoral psychology (Hiltner \& Menninger, 1963). Since then the contention has blossomed to the point that, currently, there are several journals on the relationship between the disciplines-e.g., Psychology \& Christianity, Psychology \& Judaism, Psychology and Theology, and Religion \& Health. Authorities in other disciplines have also drawn attention to the importance of spirituality, if not of organised religion, especially in times of adversity (e.g., Department of Health, 1987; Grant, 1999; Jordan, 2000; Smale, 2000). However, the WHO has yet to achieve sufficient unity among its 150 member countries to acknowledge a spiritual dimension in its definition of health (see the Ottawa Charter for Health Promotion 1986 update December 1997).

A few leading clinicians are known to have combined religio/philosophical factors with their treatment of disaster trauma. For example, psychoanalyst Viktor Frankl (1984) made the search for meaning the key to his own survival in Nazi concentration camps, and afterwards, he used it as the basis of logo therapy and existentialism. Herman (1992, p. 59) reinforced the approach by emphasizing that traumatic events "undermine the belief systems that give meaning to human experience. They violate the victim's faith in a natural or divine order and cast the victim into a state of existential crisis".

The psychiatrist Scott-Peck (1988) went further to made spirituality the core of his search in building peaceful communities. However, a similar quest led Ursano, Tzu-cheg, and Fullerton (1992) to appeal for "clear logical thinking and quantitative measures to further our understanding of the mechanisms of meaning formation and the contribution of meaning to behaviour, illness, and disease" in the military after combat. It also induced Benson and Stark (1996, ch.8) to research the physiological underpinnings of religious belief to help the recovery of troubled psychiatric patients. Then the disquiet after the September 11 terrorist attacks on the World Trade Centre in New York and the Pentagon in Washington D. C., led even the American

\footnotetext{
17 The necessity to accommodate human values in the assessment of behaviour occurred to the author earlier in his career when he ran therapy groups for prisoners (Taylor, 1964). In that setting, behaviour change depended on offenders discerning the unique combination of emotional, legal, moral, religious, and social factors behind their crimes, before developing a higher purpose in life and forming attachments with which to pursue it.
} 
Psychological Association to encourage psychologists facing "compelling challenges" to attend to their "spiritual needs individually or within a community" (Retrieved November 2, 2011, from http://www.www. apa.org/ practice/practitionerhelp.html) ${ }^{18}$.

It remains for others to pick up the argument, adjust the customary "scientific" epistemological framework for understanding human behaviour, and bring religion firmly into the wider academic fold ${ }^{19}$. Cambridge University led the way recently by establishing a Centre for Applied Psychology and Religion (Florance, 2010), and the British Psychological Society followed with a whole issue devoted to the interaction of the disciplines on the topic (The Psychologist, 2011) ${ }^{20}$.

Hence clinicians and researchers working with disaster groups were wise to accommodate different primitive beliefs as they proceed, rather than to try to refute their power. For example, after the fatal dormitory fire in Vaitupu Secondary School in the Tuvau group of islands in the South Pacific, the ghosts of the deceased (that were always considered malevolent) were said to join the evil spirits that pervaded the environment (Taylor, 2000). Terrified adults swore that they heard the clacking sound of ghosts at night. The noise made a merchant service sailor cut short his home leave to return to his ship in Europe. The evening bell-ringer was unable to perform her duty to mark the curfew for children, and a grown man had to seek the sheltering embrace of his family on the centre of his household mat before he could get to sleep, instead of vice versa. Many were fearful of going outdoors to the toilets at night. Even by day some adults were so afraid that they stopped gathering wood and vegetables by themselves. If anything, the children seemed less unnerved, and they spoke of conversations they were still able to have with the ghosts of their friends.

Normally, because of the frightening and mystical aura of ghosts associated with the scene of a tragedy, the village would have declared the whole disaster-site tapu. But because the fire had occurred in the only secondary school in the island chain, and the school had a critical function both in the education of pupils and the potential economic security of their families, it seemed appropriate for the author to raise the topic of exorcism with a the leading member of the local clergy.

\footnotetext{
${ }^{18}$ McDonald (2000) used the term spirituality to cover religious attitudes, experiential dimensions, existential wellbeing, paranormal beliefs, and religious practices. His inclusive definition offers a cohesive meaning and purpose in life, and sets a framework for human conduct and group relationships that could engender the vital attributes of personal happiness and a deep sense of belonging.

${ }_{19}$ At the turn of the 20th century, when academic psychologists were more comfortable with their parent discipline of philosophy, William James (1902) devoted a major tome to the place of religion in human behaviour. He nominated the "religious self" that combined with material and social selves to be essential for coping with life. Then in 1931, Allport and Vernon introduced the first of a sequence of scales in which the religious motive ranked with the aesthetic economic, political, social, and theoretical (Allport, Vernon, \& Lindzey, 1970), but subsequently such subjective factors were swept aside in the worship of operationism (Israel \& Goldstein, 1944). Some 50 years later, Myers (1994, pp. 329-334) made a rare attempt to integrate features of Judeo/Christianity as a personal post-script to his textbook on psychology. But shortly afterwards, Zeidner and Endler (1996) virtually ignored religion in their otherwise comprehensive (and compendious) volume on coping, except for quoting St. Augustine on their book jacket and mentioning in one line (p. 139) that seeking or finding spiritual comfort or support was a coping strategy. Shortly afterwards Beit-Hallami and Argyle (1997) published a comprehensive but inconclusive review of the relationship between psychology and religion. Shortly afterwards, Bracken (2002), with an academic background in both philosophy and psychiatry, did much to try to blend the disciplines.

${ }^{20}$ However, quite rightly journalist Tara McKelvey (2009) questioned the spiritual component of PTSD (post-traumatic stress disorder) at the expense of the psychological in the treatment of US soldiers suffering psychiatric disorder from their service in war-torn Afghanistan and Iraq (Hoge, Castro, Messer, McGurk, Cotting, \& Koffman, 2004). In the process, she cited the severe existential dilemma of an Army Chaplain suffering PTSD from: (1) his involvement in the Iraq war for which the moral justification that the enemy was said to have had weapons of mass destruction at the ready was an issue; and (2) the military assuring him that God was on his side.
} 
Not only did the Minister assure the author that he had already conducted such a cleansing procedure, but he drew him into a dawn service in which villagers took turns to express their grief before symbolically the rising sun bathed the whole congregation in daylight.

To reinforce such ethereal measures, and to help to meet the needs of the briefed in other islands in the Tuvalu chain, the author went on to suggest that: a memorial be created in the school on which the surviving pupils and the grieving relatives might sit and retain links with the decease; and to avoid perpetual despondency an annual commemorative festival be created to mark the tragedy and carry forward the high hopes of the deceased $^{21}$.

(4) Discovering and respecting the social structure of a target community is grist to the mill of anthropologists, sociologists, and ethno-psychologists. It sets the framework and hierarchy of authority and obligations within which newcomers will be expected to work, and goes some way towards ensuring a successful outcome for any approved enterprise. For example, in the South Pacific the extended family rather than the familiar Western nuclear family is the norm (Danielsson, 1956, p. 89). Relatives of grandparents, parents, and cousins all have similar obligations for the life and welfare of each other as the immediate biological family. As a consequence, families in Polynesia share their progress and happiness to a far greater extent than families in the Western world. Conversely, they also share their setbacks and feel tragedies more keenly. Consequently clinicians working in such communities are obliged to approach a wide swath of people after disasters to be sure of not overlooking members of the extended families who might be in need of help. Thus 298 people between the ages of 14 and 74 presented themselves initially to meetings on the two Islands of Funafuti and Vaitupu after a fire in the dormitory of a school that burned a matron and 18 girls alive. They represented about $7.5 \%$ of the combined population aged over 14 years in the two places. One hundred and twenty six were students, 36 were staff members of the school, and another 136 were related in some way to the survivors of the tragedy.

At screening sessions, groups of 10 listened attentively to others around the circle until their turn came to express themselves: English happened to be the second language for most of the respondents, and the indigenous medical staff was able to translate the contributions of the others. As to be expected, the only difference between the generations was that the younger participants had fewer words to describe their feelings than the elderly (Boreham, Homasi, Marks, Rabukawaqa, Talia, \& Taylor, 2001).

(5) On an assignment in Fiji, preliminary inquiries with Dr Henry Aghanwa Senior Lecturer in Psychiatry at the Fiji School of Medicine lead the author to expect either the display of symptoms of the somatic kind, or signs of culturally-specific symptoms that sometimes are found in non-Western communities (Diagnostic \& Statistical Manual of Mental disorders IV-TR. 2000, Appendix 1). But in the event neither occurred. Instead, the survivors (pupils and staff) presented the familiar stress-related symptoms of avoidance, intrusive imagery, episodes of reliving the experience, and sleep disturbance that are typically found in Western cultures.

(6) Fortunately, the authorities had made arrangements to keep school pupils together on the main island of Funafuti after the tragedy, rather than disperse them to home to their parents throughout the island chain. The continued close association had the effect of helping the pupils to regain their emotional security as a group that had endured a phenomenal experience - as other researchers in other parts of the world had found in their post-disaster studies with different populations (Hoiberg \& McCaughey, 1982; Yule \& Williams, 1990).

${ }^{21}$ An invitation to return to celebrate the first anniversary of the tragedy confirmed that both suggestions had been well taken up. 
(7) Health professionals were wise not to give undue attention immediately either to any particular psychological symptoms that casualties might report, or to any signs they might themselves observe, but to allow a few days grace in which the vulnerable might use their inner strength and begin to regain their composure. Within the limits of common sense, the time for professionals to register features of psychopathology comes later, should the casualties find intrusive thoughts, avoidance behaviour, and the state of high arousal interferes seriously with their everyday lives (Young, Ford, Ruzek, Friedman, \& Gusman, 1998; Raphael, 2000) ${ }^{22}$.

The delay should not put people unduly at risk because, as the WHO (2003, p. 4) indicated:

Most acute mental health problems during the acute emergency phase are best managed without medication following the principles of "psychological first-aid" (i.e. listen, convey compassion, assess needs, ensure basic physical needs are met, not force talking, ... mobilise company from preferably family or significant others, encourage but do not force social support, protect from further harm.

(8) Fostering the "placebo effect" deserves a mention, because it generates hope among survivors for recovery, and negates the stultifying power of its counterpart, the "nocebo effect". It is consistent with an adaptation of Nietzsche's aphorism, i.e., "that which does not kill me (might make) me strong”. The change in terminology implies that casualties are members of a provisional rather than a permanent category. The term applies to people who have survived the initial impact of a life-threatening event of some magnitude, and might even have derived benefit psychologically from having survived a catastrophic experience (Tedeschi, Park, \& Calhoun, 1998). In fact, and without going quite so far as Samuel Johnson to say that "when a man knows he is to be hanged in a fortnight, it concentrates his mind wonderfully", there is truth in the saying that the awareness of death causes a re-examination of value systems (Ursano et al., 1992).

(9) If appropriate for time and place, humour sustains morale and can enable some casualties to function with equanimity no matter how devastating the situation in which they find themselves (Moran \& Massam, $1997)^{23}$. In-group "black humour" is known to have helped workers sustain the cohesion, and to set aside the emotional aspects of a difficult task until a more suitable time for reflection. For example, workers in a mortuary after a mass emergency obtained light relief when responding to a cry "give us a hand"-by asking whether a right hand or a left was preferred because they had a bag of each. But its divulgence to outsiders is liable to be misunderstood and its disclosure causes the mortuary workers embarrassment.

Both Lefcourt (2000) and Martin (2007) established a place for humour in the clinical armamentarium, and some therapists are known to promote its use specifically for stress relief, pointing to the bio-chemical/neuro/psycho/social benefits of laughter.

The emergence of humour in an individual or a community after a period of stress can also be taken as a sign of recovery (Retrieved December 27, 2011, from http://bouldertherapist.com/html/humor/... /12signGoodHealth.html). An amputee created a ripple of laughter at a community meeting when he spoke of avoiding evacuation after a cyclone by asserting that he would not leave without his wooden leg. At the same meeting, another survivor induced a roar of laughter when she spoke of finding herself swimming among the

\footnotetext{
${ }^{22}$ At the extreme, one father could barely contain an impulse to murder the prime-minister for denying him access to his daughter. Subsequently the resident medical staff monitored the man's progress and kept a watchful eye for any of their community whose adverse reactions might emerge later.

${ }_{23}$ The patriotic song of the British Army in World War II- "We're going to hang out the washing on the Siegfried Line”-immediately springs to mind.
} 
pigs after the inundation ${ }^{24}$.

(10) Encountering the casualty described in the previous paragraph led the author to invite her to retrace and describe her disaster-experience in situ, instead of reconstructing it from memory. En route she revived the totality of her watery survival by leading the author from her house through the bush tracks to the piggery, stopping here and there to fill in details of the plight of her neighbours and the animals that swept past in the torrential downpour. In the process, she re-experienced the full intensity of her fears, and in the author opinion she made more progress towards recovery in 40 minutes of actuality than she would have done from several sessions of conventional therapy.

Not every disaster situation might offer the chance for such a reconstruction of stressful experience in situ, but therapists should be on the look-out to take advantage of them.

(11) A responsible role for the news media comes into consideration, because of the impact reporters have on the well-being and responsiveness of their listeners, readers, and viewers ${ }^{25}$. Too often journalists harass disaster casualties to bleed their emotions for the titillation of others. They strive to provoke extremes of either compassion or anxiety, or worse, to satisfy the prurient. Their efforts are designed to raise critical audience/reader ratings that attract advertisers seeking more exposure for their products, rather than designed to help any casualty.

With regard to the 9/11 attacks on the World Trade Center, a study showed that New Yorkers who viewed the televised images of the event above seven times were more likely to suffer posttraumatic stress disorders and or depression than a control group that had seen less (Ahern, Galea, Resnick, Kilpatrick, Bucuvalas, Gold, \& Vlahov, 2002). Down here in New Zealand, the crucial 15-minute tape of the planes colliding into the twin towers and the immediate aftermath was played almost hourly for two-days. In response to the author's question, one announcer said the repetition was deliberately intended to create "an indelible impression" on viewers. However, to his credit, the veteran journalist Langewiesche (2003) fulfilled his commission to cover the same disaster at length, and with a degree of independence and objectivity that commanded respect.

Just a few years earlier after a Bay of Plenty earthquake (Taylor, 1988), an irresponsible radio announcer said that the emergency responders had not begun to count the bodies in a city some $150 \mathrm{kms}$ from epicentre. His report led agitated relatives far away in Europe to seek confirmation that their loved ones were safe. In fact, today, years after the event, the bodies have still not been counted, because there were never any from the disaster to be counted! Then most recently after reports of a tsunami in nearby Samoa, a well-known TV presenter persistently inquired whether the local populace had yet begun to panic - as if he were expecting them to respond in such a way.

The author's response was to challenge the news media to fulfil the once responsible and proud function of the "fourth estate", at least in reporting disasters (Taylor, 2006a). Subsequently, the NZ Ministry of Civil Defence and Emergency Management let contracts for this purpose to the news media, but it left the organisations to train their own staff in such matters.

\footnotetext{
${ }^{24}$ Such incidents enabled the author to respond in the positive when the authorities called unexpectedly for advice as to whether a whole island should be evacuated. The author responded by saying that the survivors were in good spirits. They had sufficient food, fresh water, clothing, and shelter, and had organised themselves into gangs for cleaning-up, preparing meals, child-minding, and so on. The adolescents were also beginning to make a nuisance of themselves once more a period (Here the author pays tribute to ethno-psychologist Ernest Beaglehole's early mentoring of the author as a student, and to a seminal paper by Aberle, Cohen, Davis, Levy, and Sutton (1949-1950) that conceptualised the vital requirements of a functional society).

${ }^{25}$ Cantril's (1947) comment on the random behavior of listeners to a surprise broadcast of H. G. Wells' drama War of the World.
} 
(12) No matter how prestigious the authority recommending specific treatments, health professionals on the ground remain accountable for the potency or otherwise of their interventions ${ }^{26}$. To determine that matter, clinicians and their organizations have to adopt appropriate procedures for collecting data to evaluate their work to the satisfaction of independent critics (Smith, 2004). In particular, the initial and follow-up measures have to be both valid, psychometrically sound, and culturally appropriate for everyone in a designated population ${ }^{27}$.

The latter is important, because in the case of emergency personnel, if not of the primary casualties, studies have shown that neither single nor multiple debriefing sessions prevented the emergence of PTSD (post-traumatic stress disorder) symptoms as its exponents had promised (Rose Bisson, Churchill, \& Wesseley, 2000; Roberts, Kitchiner, Kenardy, \& Bisson, 2009) ${ }^{28}$.

(13) A miscellany of sundry matters are also likely to arise from involvement with disasters. For example, a walk around the cyclone-damaged island provoked thoughts that might be used for the reconstruction, because the round shape of buildings seemed to have deflected the elements more than those that were square. Then, regarding the fatal fire in the school dormitory, questions arose as to why the girls were locked in so firmly at night with windows barred and no emergency release on the inside of the doors. The explanation offered, common to many schools in the South Pacific, was that the security protected the girls from pregnancy by stopping male interlopers getting in and the occupants from slipping out.

In considering protective measures, the authorities were disinclined to follow leads from the Western world on the matter, because of the notoriously high pregnant rates recorded among the adolescents of those countries (UNICEF, 2001). Instead, it ring-fenced the dormitories, introduced chemical fire extinguishers, and introduced regular fire-drills and evacuation procedures as secondary preventive measures.

Finally, with regard to the Fiji hostages, the plaintiff cry for justice from the wife of a parliamentarian, led the author to wrestle with that vexed philosophical question once again in the author's career. The woman was at a loss understand why a group of insurgents had taken hostage her earnest, highly principled, and hard-working husband. In her extreme anxiety and fear of meeting a similar fate, she had hired a guard and turned her home into a virtual prison for her self-protection. On further consideration, the author came to construe justice as having a strong social component as well as those of the familiar civil and criminal, and in due time the author sought the support of criminologists, lawyers, philosophers, psychologists, social workers, and theologians to contribute to the theme (Taylor, 2006b; 2009).

\section{Conclusion}

Other psychologists will have their own catalogue of dissonance between the ideal and the actual from their work after disasters. They will also have grappled long after with significant questions that demanded

\footnotetext{
${ }^{26}$ Although the joint National Child Traumatic Stress Network and National Center for PTSD (2008) provided helpful guidelines on the provision of psychological first aid for survivors of disasters, it did not address the need for them to collect data for clinical follow-up and/or research purposes.

27 This required validation and standardisation of the familiar measures for the target population in the setting proved satisfactory, and it enabled the researchers to leave handy tools for local clinicians to use in their regular practice (e.g., Aghanwa, Walkey, \& Taylor, 2003; Taylor, Aghanwa, \& Walkey, 2003).

${ }^{28}$ The Working Party of the British Psychological Society (Tehrani, 2002) took less of a hard line in appraising the effectiveness of debriefing. After considering the need, measures to meet it, the professional obligations of those involved, and reviewing the evidence, it concluded "There is still work to be done before it is possible to prove that psychological debriefing is effective as an early intervention following traumatic exposure. However, the picture on what needs to be done is becoming clear” (pp. 74-75).
} 
further attention. If the sample presented here were to encourages them to share more of their own experience, and recruit others to work on the remedies, the author shall be well satisfied. If it were to elevate the study of disasters to its rightful place in the social sciences, the author would be even more so.

\section{References}

Aberle, D. F., Cohen, A. K., Davis, A. K., Levy, Jnr., M. J., \& Sutton, P. X., (1949-1950). The functional prerequisites of a society. Ethics: An International Journal of Social, Political, \& Legal Philosophy, LX, 100-111.

Aghanwa, H., Walkey, F. H., \& Taylor, A. J. W. (2003). The psychometric cross-cultural validation of the impact of events scale. Pacific Health Dialogue, 10(2), 66-70.

Ahern, J., Galea, S., Resnick, H., Kilpatrick, D., Bucuvalas, M., Gold, J., \& Vlahov, D. (2002). Television images and psychological symptoms after the September 11 terrorist attack. Psychiatry, 65(4), 289-300.

Ali, T. (2003). The clash of fundamentalisms: Crusades, Jihads and modernity. London: Verso.

Allport, G. W., Vernon, P. E., \& Lindzey, G. (1970). The study of values (3rd ed.). New York: Houghton Mifflin.

Bakan, J. (2004). The corporation: The pathological pursuit of profit and power. London: Constable.

Becker, E. (1973). The denial of death. New York: The Free Press.

Beit-Hallahmi, B., \& Argyle, M. (1997). Religious behaviour, belief and experience. London: Routledge.

Benson, H., \& Stark, M. (1996). Timeless healing: The power and biology of religious belief. London: Simon \& Shuster.

Berry, N. H. (1968). 1879 and all that. Invited paper for the London Conference of the British Psychological Society, December 18, Private circulation, p. 20.

Bollard, A., \& Gaitanos, S. (2010). Crisis: One central bank governor and the global financial collapse. Auckland University Press.

Bolton, G. B. (2008). Aid and other dirty business: An insider reveals how good intentions have failed the world's poor. London: Ebury Press.

Boreham, P., Homasi, S., Marks, I., Rabukawaqa, V., Talia, L., \& Taylor, A. J. W. (2001). A trauma team in Tuvalu. Fiji General Practitioner, 8(1), 685-688.

Bracken, P. (2002). Trauma: Culture, meaning and philosophy. London: Whurr.

Brook, R. R., Basher, R. R., Bruce, J. P., Parsons, S. A., \& Sullivan, J. P. (1991). The changing climate in paradise: Feasibility study on climate monitoring and impacts in the South West Pacific. Wellington: Bureau of Meteorology.

Burns, P. (2006). Justice, torture and restoration. In A. Taylor (Ed.), Justice as a basic human need. New York: Nova Science.

Cantril, H. (1947). The invasion from Mars. In T. M. Newcomb, \& E. L. Hartley (Eds.), Readings in social psychology. New York: Henry Holt.

Chamberlain, K. (2009). Constructing knowledge in contemporary psychology: Some critical comments. Psychology Aotearoa, $1(1), 47-52$.

Danielsson, B. (1956). Love in the South Seas. London: Allen \& Unwin.

Dent, H. S. (2009). The great depression ahead: How to prosper in the crash that follows the greatest boom in history. Melbourne: Schwartz.

Department of Health. (1987). The undiscovered country: Customs of the cultural and ethnic groups of New Zealand concerned with death and dying (p. 75). Wellington, N.Z.: Authors.

Diagnostic \& Statistical Manual of Mental Disorders IV-TR. (2000). Washington, D.C.: American Psychiatric Association.

Diamond, J. (1999). Guns, germs, and steel: The fates of human societies. New York: Norton.

Diamond, J. (2005). Collapse: How societies choose to fail or survive. London: Penguin.

Doherty, G. W. (2007). Crisis intervention training for disaster workers: An introduction. Laramie, W.Y.: Rocky Mountain Disaster Mental Health Institute Press.

Doherty, G. W. (2010). From crisis to recovery: Strategic planning for response, resilience, and recovery. Laramie, W.Y.: Rocky Mountain Disaster Mental Health Institute Press.

Drabek, T. E. (1986). Human system responses to disaster: An inventory of sociological findings. New York: Springer-Verlag.

Drabek, T. E. (2010). The human side of disaster. London: CRC/Taylor \& Francis.

Durie, M. H. (1985). A Maori perspective of health. Social Science and Medicine, 20(5), 483-486.

Erikson, K. (1994). A new species of trouble: Explorations in disaster, trauma, and community. New York: Norton. 
Fanelli, D. (2009). How many scientists fabricate and falsify research? A systematic review and meta-analysis of survey data. PLOS ONE, 4(5), e5738. doi:10.1371/journal.pone.0005738

Figley, C. (1994). Compassion datigue: Coping with secondary traumatic stress disorder in those who treat the traumatized. New York: Routledge.

Florance, I. (2010). Religion is a powerful human reality: Ian Florance talks to Sara Savage about her life and work. The Psychologist, 23(3), 242-245.

Francis, R. D. (1999). Ethics for psychologists: A handbook. Leicester: The British Psychological Society.

Frankl, V. (1984). From death camp to existentialism. Boston: Beacon.

Grant, R. (1999). Spirituality and trauma: An essay. Traumatology, 5(1). Retrieved from http://www.fsu..edu/ trauma/T-088.html

Hancock, D., Williams, M., \& Taylor, A. J. W. (1998). Psychological impact of cadavers and prosections on physiotherapy and occupational therapy students. Australian Journal of Physiotherapy, 44(4), 247-255.

Hancock, D., Williams, M., Taylor, A. J. W., \& Dawson, B. (2004). Impact of cadaver dissection on medical students. New Zealand Journal of Psychology, 33(1). 17-25.

Harrison, A. A., Taylor, A. J. W., \& Wichman, H. (2009). Behavioural factors and planetary defense. In I. Bekey (Ed.), Dealing with the threat to earth from asteroids and comets. International Academy of Astronautics.

Health \& Safety in New Zealand Mortuaries. (1998). Wellington: Department of Labour. Retrieved from www.osh.govt.nz/order/catalogue/pdfs/occ1mortuary.pdf

Herman, J. L. (1992). Trauma and recovery. London: Pandora.

Hiltner, S., \& Menninger, K. (Eds.). (1963). Constructive aspects of anxiety. New York: Abingdon Press.

Hobfoll, S. E., Watson, P., Bell, C. C., Bryant, R. A., Brymer, M. J.,... Friedman, M. J. (2007). Five essential elements of immediate and mid-term mass trauma intervention. Psychiatry, 70(4), 283-315.

Hoge, C. W., Castro, C. A., Messer, S. C., McGurk, D., \& Cotting, D. I., \& Koffman, R. L. (2004). Combat duty in Iraq and afghanistan, mental health problems, and barriers to care. New England Journal of Medicine, 351, 13-22. Retrieved January 28, 2010, from http://content.nejm.org/cgi/content/full/351/1/13

Hoiberg, A., \& McCaughey, B. G. (1982). Collision at sea: The traumatic after-effects (Report 81/39, pp. 25). San Diego: Naval Medical Research \& Development Command.

International Federation of Red Crescent and Red Cross Societies. (1995). World Disasters Report. Authors: Oxford University Press.

International Federation of Red Crescent and Red Cross Societies. (1998). World Disasters Report. Authors: Oxford University Press.

Israel, H., \& Goldstein, B. (1944). Operationism in psychology. Psychological Review, 51, 177-188.

James, W. (1902). The varieties of religious experience: A study in human nature. London: Longman \& Co..

Jordan, M. R. (2000). A spiritual perspective on trauma and treatment. NCP Clinical Quarterly, 5(1). Retrieved from http://www.ncptsd.org/treatment/cq/v5/nl/jordan.html

Keys, D. (1999). Catastrophe: An investigation into the origins of the modern world. London: Century.

Korten, D. C. (1996). When corporations rule the world. West Hartford, C.T.: Kumarian Press \& Berret-Koehler.

Langewiesche, W. (2003). American ground: Unbuilding the World Trade Center. New York: North Point.

Laquer, W. (1987). The age of terrorism. Boston: Little Brown \& Co..

Lefcourt, H. M. (2000). Humor: The psychology of living buoyantly. New York: Plenum.

Luomala, K. (1984). Polynesian mythology. In M. Leach, \& J. Fried (Eds.), Funk and Wagnall's standard dictionary of folklore mythology and legend (pp. 876-879). San Francisco: Harper.

Martin, R. A. (2007). The psychology of humor: An integrative approach. New York: Academic Press.

McClure, J., Wills, C., Johnston, C., \& Recker, C. (2011). How the 2010 Canterbury (Darfield) earthquake affected earthquake risk perception: Comparing citizens inside and outside the earthquake region. Australasian Journal of Disaster \& Trauma Studies, 2, 3-10.

McClure, J., \&Velluppillai, J (2013). The effects of news media reports on earthquake attributions and preventability judgments: Mixed messages about the Canterbury earthquake. Australasian Journal of Disaster \& Trauma Studies, 1, 27-35.

McDonald, D. A. (2000). Spirituality: Description, measurement, and relation to the five-factor model of personality. Journal of personality, 68(1), 153-197.

McKelvey, T. (2009). God, the army, and PTSD. New York Times, 17 December. 
McLean, I., Oughton, D., Ellis, S., Wakelin B., \& Rubin, C. B. (2012). Review of the Civil Defence Emergency Management Response to the 23 February Christchurch earthquake. Wellington, N.Z.: Ministry of Emergency Management. pp. 269.

Miller, J. G. (1991). Applications of living systems theory to life in space. In A. A. Harrison, Y. A. Clearwater, \& C. P. McKay (Eds.), From Antarctica to outer space: Life in isolation and confinement (pp. 177-197). New York: Springer-Verlag.

Miller, W. R. (Ed.). (1999). Integrating spirituality into treatment: Resources for practitioners. Washington, D.C.: American Psychological Association.

Moran, C., \& Massam, M. (1997). An evaluation of humour in emergency work. Australasian Journal of Disaster and Trauma Studies, 3. Retrieved November 21, 1997, from http://www.massey. ac.nz/-trauma/

Myers, D. G. (1994). Exploring social psychology. New York: McGraw-Hill.

NASA Astronaut Health Care System Review Committee. (February-June, 2007). Report to the Administrator. Retrieved from September 9, 2010, from http://www.nasa. gov/pdf/183113main_NASAhealthcareReport_0725FINAL.pdf

National Child Traumatic Stress Network and National Center for PTSD. (2008). Psychological first aid: Field operations guide (2nd ed.). Washington, D.C.: Authors.

O’Donohue, W. (1989). The (even) bolder model: The clinical psychologist as a metaphysician-scientist-practitioner. American Psychologist, 44(12), 1460-1468.

Ottawa Charter for Health Promotion 1986. (update December 1997). Retrieved from http://www.who.dk/

Pappworth, M. H. (1967). Human guinea pigs: Experiments on man. Harmondsworth: Pelican Books.

Ramakrishna, K. (2005). The "root causes" of terrorism: A new approach to an old problem. Paper delivered to the August National Counter Terrorism Capability Seminar, Victoria University of Wellington, New Zealand.

Raphael, B. (2000). Disaster mental health handbook: An educational resource for health professionals involved in disaster management. North Sydney: New South Wales Centre for Mental Health.

Roberts, N. P., Kitchiner, N. J., Kenardy, J., \& Bisson, J. (2009). Systematic review and meta-analysis of multiple-session early interventions following traumatic events. American Journal of Psychiatry, 166(3), 293-301.

Rose, S., Bisson, J., Churchill, J., \& Wesseley, S. (2000). Psychological debriefing for preventing post traumatic stress disorder (PTSD) review. The Cochrane Collection (p. 48). London.

Russell, Lord E. F. L. (1955). The scourge of the swastika: A short history of Nazi war crimes (7th ed.). London: Cassell.

Sagan, C. (1997). The demon-haunted world: Science as a candle in the dark. London: Headline.

Scott-Peck, M. (1988). The different drum. London: Random Century.

Silke, A. (Ed.). (2003). Terrorists, victims and society. New York: Wiley.

Smale, S. (2000). The Port Arthur anniversary services. Australian Journal of Emergency Management, 15, 2-5.

Smith, L. M. (2004). Measuring protective behaviours for perceived risks of hazards. In D. Paton, J. M. Violanti, C. Dunning, \& L. M. Smith (Eds.), Managing traumatic stress risk: A proactive approach (chap. 4). Springfield I.L.L.: Thomas.

Sokal, A. (1996). Transgressing the boundaries: Towards a transformative herme-neutics of quantum gravity. Social Text, 46/47, 217-252. Retrieved November 1, 2004, from http://www.physics.nyu.edu/faculty/sokal/index.html

South Pacific Bureau for Economic Co-operation. (1979). National disaster prevention, preparedness and rehabilitation meeting: Summary record. SPEC 79/25.

Sutherland, E. H. (1949). White collar crime. New York: Holt Reinhart \& Winston.

Taylor, A. J. W. (1964). The differentiation of guilt patterns in prisoners. American Journal of Psychotherapy, 18(3), 470-474.

Taylor, A. J. W. (1967). An evaluation of group psychotherapy in a girls borstal. International Journal of Group Psychotherapy, $17(2), 168-177$.

Taylor, A. J. W. (1984). Architecture and society: Disaster studies and human stress. Ekistics: The Problems \& Science of Human Settlements, 308, 446-451.

Taylor, A. J. W. (1987). A taxonomy of disasters and their victims. Journal of Psychosomatic Research, 31(4), 535-544.

Taylor, A. J. W. (1988). Coping with the earthquake. In Q. W. Ruscoe (Ed.), Walking on jelly: The bay of plenty earthquake. Wellington: Department of Scientific and Industrial Research.

Taylor, A. J. W. (1989). Disasters and disaster stress. New York: AMS Press.

Taylor, A. J. W. (1990). A pattern of disasters and victims. Disasters: The Journal of Disaster Studies \& Management, 14(4), 291-300.

Taylor, A. J. W. (1999). Value-conflict arising from a disaster. Australasian Journal of Disaster \& Trauma Studies. Retrieved from http://www.massey.ac.nz/ trauma/issues/1999-2/ taylor.htm 
Taylor, A. J. W. (2000). Tragedy and trauma in Tuvalu. Australasian Journal of Disaster \& Trauma Studies. Retrieved from http://www.massey.ac.nz/ trauma/issues/2000-2/ taylor.htm

Taylor, A. J. W. (2003). Bringing “complex terrorism” and “corporate malfeasance” into a classification schema for disasters. Australian Journal of Emergency Management, 18(1), 27-34.

Taylor, A. J. W. (2006a). Consolidating the role of the fourth estate in disaster work. International Journal of Mass Emergencies \& Disasters, 14(1), 145-167.

Taylor, A. (Ed.). (2006b). Justice as a basic human need. New York: Nova Science.

Taylor, A. J. W. (2007). Defusing terrorism of terror. In B. Bongar, L. Beutler, P. Zimbardo, L. M. Brown, \& J. N. Breckenridge (Eds.), The psychology of terrorism (chap. 24). Oxford University Press.

Taylor, A. J. W. (2009). Justice as a basic human need: An invited paper on a topic at the cutting edge of psychology. New Zealand Journal of Psychology, 38(2), 8-11.

Taylor, A. J. W., Aghanwa, H., \& Walkey, F. H. (2003). Norms for Fiji and a cross-cultural validation of the general health questionnaire (GHQ 20). Pacific Health Dialogue, 10(2), 62-65.

Taylor, A. J. W., \& Frazer, A. G. (1981). Psychological sequelae of operation overdue following the DC10 air crash in Antarctica (p. 72). Wellington: Victoria University.

Taylor, A. J. W., Nailatikau, S., \& Walkey, F. H. (2002). A hostage trauma assignment in Fiji. Australasian Journal of Disaster \& Trauma Studies. Retrieved from http://www.massey.ac.nz/ trauma/issues/2002-2/taylor.htm

Taylor, I. (Ed.). (1990). The social effects of free market policies: An international text. New York: Harvester Wheatsheaf.

Tedeschi, R. D., Park, C. L., \& Calhoun, L. G. (Eds.). (1998). Posttraumatic growth: Positive changes in the aftermath of crisis. Mahwah N.J.: Erlbaum.

Tehrani, N. (2002). Psychological debriefing: Professional practice board working party. Leicester: The British Psychological Society.

Tenner, E. (1996). Why things bite back: Predicting the problems of progress. London: Fourth Estate.

The 9/11 Commission Report: Final report of the National Commission on Terrorist attacks upon the United States. (n.d.). New York Norton.

The Psychologist. (2011). Special issue: Psychology, religion and spirituality (Vol. 24, p. 4).

Townsend, E., Walker, D. M., Sargeant, S., Vostanis, P., Hawton, K., Stocker, O., \& Sithole, J. (2010). Systematic review and meta-analysis of interventions relevant for young offenders with mood disorders, anxiety disorders, or self-harm. Journal of Adolescence, 33, 9-20.

UNDRO News. (1990). Cyclone ravages in several Pacific islands, March/April, pp. 4-5.

UNICEF. (2001). A league table of teen-age pregnancy in rich nations. Innocenti Report Card 3, July. Florence: Innocenti Research Centre.

United Nations. (2005). In larger freedom: Towards development, security, and human rights for all (Report of the Secretary-General, A/59/2005, pp. 62). New York.

Ursano, R. J., Tzu-Cheg, K., \& Fullerton, C. S. (1992). Post traumatic disorder and meaning: Structuring human chaos. Journal of Nervous and Mental Disease, 180(12), 756-759.

Victorian, A. (1996). United States, Canada, and Britain: Partners in mind control. Retrieved April 11, 2005, from http://www.peace.ca/mindcontroloperations.htm

Wilkinson, R., \& Pickett, K. (2009). The spirit level: Why equality is better for everyone. London: Penguin.

Williams, P., \& Wallace, D. (1989). Unit 731: The Japanese Army's secret of secrets. London: Hodder \& Stoughton.

World Health Organisation. (2004). Management of dead bodies in disaster situations. Disaster Manuals and Guidelines Series \# 5. Washington D. C..

Young, B. H., Ford, J. D., Ruzek, J. I., Friedman, M. J., \& Gusman, F. D. (1998). Disaster mental health service: A guidebook for clinicians and administrators. White River Junction V.T.: Department of Veterans Affairs.

Yule, W., \& Williams, R. M. (1990). Post-traumatic reactions in children. Journal of Traumatic Stress, 3(2), 279-295.

Zeidner, M., \& Endler, N. (Eds.). (1996). Handbook of coping: Theory, research, applications. New York: Wiley. 